\title{
PENGARUH PELATIHAN, DISIPLIN, DAN PENGEMBANGAN KARIR TERHADAP KINERJA KARYAWAN OUTSOURCING PT. GARDAUTAMA
}

\author{
Maskarto Lucky Nara Rosmadi \\ Program Studi Manajemen, STIE Kridatama, Bandung
}

\begin{abstract}
Abstrak: Penelitian ini ditujukan untuk mengetahui pengaruh Pelatihan, Disiplin, dan pengembangan karir terhadap kinerja karyawan PT. Gardautama. Metode yang digunakan adalah analisis jalur, yaitu untuk mendapatkan gambaran, pola hubungan dan pengaruh dari variabelvariabel penelitian yang telah ditetapkan. Berdasarkan hasil penelitian, pelatihan pada tingkatan baik, disiplin pada posisi yang kurang baik, serta pengembangan karir ada pada tingkatan baik. Secara umum, pelatihan, disiplin, dan pengembangan karir berpengaruh terhadap kinerja karyawan, dan pengaruh pelatihan adalah paling signifikan terhadap kinerja karyawan. Pengaruh secara parsial variabel pelatihan terhadap kinerja karyawan adalah sebesar $28,60 \%$, variabel disiplin terhadap kinerja karyawan adalah sebesar $27,20 \%$, dan variabel pengembangan karir terhadap kinerja karyawan adalah sebesar $20,70 \%$. Pengaruh secara simultan pelatihan, disiplin, dan pengembangan karir terhadap kinerja karyawan adalah sebesar 76,50\%, sedangkan 23,50\% dipengaruhi oleh variabel lain yang tidak diteliti. Dari hasil penelitian, maka variabel pelatihan, disiplin, dan pengembangan karir memberikan pengaruh yang signifikan terhadap kinerja karyawan PT. Gardautama.
\end{abstract}

Kata kunci: Disiplin, Kinerja, Pelatihan dan Pengembangan Karir

\begin{abstract}
This research is aimed to know the influence of Training, Discipline, and career development on employee performance of PT. Gardautama. The method used is path analysis, which is to get the picture, relationship pattern and influence of research variables that have been determined. Based on the results of research, training at a good level, discipline in a poor position, as well as career development is on a good level. In general, training, discipline, and career development affect employee performance, and the impact of training is most significant on employee performance. The partial effect of training variable on employee performance is $28,60 \%$, discipline variable to employee performance is equal to $27,20 \%$, and career development variable to employee performance is equal to $20,70 \%$. The simultaneous effect of training, discipline, and career development on employee performance is $76.50 \%$, while $23.50 \%$ is influenced by other variables that are not examined. From the results of research, the variables of training, discipline, and career development have a significant effect on the performance of employees of PT. Gardautama.
\end{abstract}

Keywords: Discipline, Performance, Training, Career Development

\section{PENDAHULUAN}

Pembangunan yang berlangsung di Indonesia saat ini tidak hanya membangun secara pisik, tetapi juga nonpisik berupa meningkatkan kualitas sumber daya manusia. Dalam persaingan global saat ini, dunia kerja sangat membutuhkan orang yang bisa berpikir untuk maju, cerdas, inovatif serta mampu berkarya dengan semangat yang tinggi dalam menghadapi perkembangan jaman. Dalam kondisi saat ini peran dari sumber daya manusia sendiri 
mempunyai peranan penting dalam suatu lembaga, juga diprioritaskan pada aspek manajerial yang matang dalam pengelolaan organisasi.

Menurut Fauzan Muttaqin (2014), setiap organisasi pemerintah maupun swasta akan fokus pada orientasi pengembangan usaha jangka panjang, yaitu meningkatkan pendapatan usaha yang sekaligus berpengaruh pada peningkatan kesejahteraan para pegawai. Hal ini merupakan salah satu indikator terciptanya Good Corporate Governance sebuah Perusahaan. Sedangkan Joko Setiawan (2014) berpendapat, bahwa peningkatan kualitas, efisiensi dan efektifitas tidak hanya tergantung pada teknologi mesin-mesin modern, dan adanya modal yang cukup saja. Namun semua faktor tersebut tidak akan terjadi apa-apa tanpa adanya dukungan dari sumber daya manusia yang baik dan bisa mengembangkan kemampuan dan keahlian mereka serta dapat menunjukkannya dalam peningkatan grafik produktivitas kerja.

Persaingan diberbagai sektor membuat proses pengelolaan dan pemeliharaan manajemen organisasi semakin mendapat perhatian yang serius dari seluruh elemen yang ada dalam organisasi untuk menciptakan sebuah sistem manajerial yang tangguh dan mampu mengikuti perkembangan jaman. Sumber daya manusia yang ada dalam hal ini karyawan pada suatu organisasi, tentunya berusaha bekerja dengan kemampuan yang mereka miliki agar dapat mencapai sasaran yang perusahaan inginkan. Rasa aman akan suasana kerja yang mampu mendorong karyawan untuk lebih berdedikasi tinggi dalam menyelesaikan tugas yang diberikan oleh pimpinan. Kondisi kerja yang aman semacam ini, serta didukung rekan kerja yang dapat diajak untuk bekerja sama dalam berbagai aktivitas merupakan keinginan dari setiap karyawan di suatu instansi atau organisasi. Garry Jacob dalam Kaswan (2010) mengemukakan bahwa "sarana terbaik untuk memberikan perhatian kepada karyawan adalah menaruh perhatian pada pekerjaan yang mereka lakukan dan memberi tiap karyawan kesempatan untuk terus mempelajari keterampilan dan memperoleh pengetahuan baru serta melaksanakan tanggung jawab baru sesuai kapabilitasnya".

Untuk meningkatkan kinerja karyawan dapat dilakukan melalui program pelatihan yang disesuaikan dengan perkembangan serta kemajuan ilmu pengetahuan dan teknologi dalam bentuk motivasi yang tidak terlepas dari program perencanaan tenaga kerja, sehingga sumber daya manusia tidak lagi menjadi beban, tetapi merupakan asset yang mampu bekerja secara produktif. Hal ini mengisyaratkan bahwa dalam program peningkatan kemampuan profesional, sumber daya manusia (SDM) sebagai bagian dari perencanaan tenaga kerja dalam suatu sistem nasional memerlukan adanya keterpaduan dan arah yang jelas serta berkelanjutan dalam jalur pelatihan dan pengembangan. 


\section{Jurnal Bisnis Manajemen dan Informatika}

Berkaitan dengan kinerja, Peter Drucker (2008), mengemukakan pendapatnya bahwa "kinerja yang hebat tidak ada kaitannya dengan rasa takut gagal...., tentu saja, orang melakukan hal terbaik yang bisa dilakukannya." Seorang manajer memiliki tanggung jawab untuk mengusahakan agar pekerjaan pada unitnya dapat dilaksanakan dalam jangka waktu yang cukup beralasan dan dengan biaya yang sesuai”. Kemudian Jack Fitz-enz dan Barbara Davison (2011), mengungkapkan pendapatnya, bahwa manajemen kinerja melayani banyak tujuan perusahaan. Hal ini dapat menambah motivasi dan produktivitas, mendukung pencapaian tujuan strategis perusahaan, serta memfasilitasi perencanaan dan perubahan strategis. Salah satu upaya meningkatkan kinerja karyawan adalah dengan mengadakan kegiatan bagi tercapainya tujuan organisasi. Kiranya tidak dapat disangkal bahwa keberhasilan suatu organisasi, sangat tergantung pada sistem pelatihan yang diterapkan dalam organisasi yang bersangkutan. Dengan demikian kualitas karyawan yang terdapat dalam suatu organisasi memiliki peranan yang sangat penting dalam keberhasilan organisasi dalam menyelenggarakan berbagai kegiatannya.

Eli Yulianti (2015), berpendapat, bahwa Pelatihan merupakan proses pengembangan diri kepada karyawan agar bisa bekerja lebih terampil dan meningkatkan pengetahuan maupun keahlian karyawan. Dengan pelatihan yang dilakukan perusahaan karyawan bisa mengetahui bagaimana bekerja dengan baik dan benar sesuai dengan standar operasional yang ditetapkan perusahaan. Dalam kaitan disiplin, Mathias dan Jackson (2002), berpendapat, bahwa Disiplin yang efektif sebaiknya diarahkan pada perilakunya dan bukan pada karyawan secara pribadi, karena alasan untuk pendisiplinan adalah meningkatkan kinerja. Dengan adanya disiplin kerja yang maksimal dari tenaga kerja, maka secara langsung akan berdampak bagi peningkatan produktivitas yang membawa hasil bukan saja bagi perusahaan tetapi juga bagi karyawan. Hal ini akan berpengaruh terhadap prestasi kerja karyawan yang pada akhirnya akan meningkatkan karir bagi tenaga kerja yang bersangkutan.

Gomes (2003), berpendapat pengembangan karir merupakan gabungan dari kebutuhan pelatihan di masa akan datang dan perencanaan sumber daya manusia. Dari sudut pandang pegawai, pengembangan karir memberikan gambaran mengenai jalur-jalur karir di masa akan datang didalam organisasi dan menandakan kepentingan jangka panjang dari organisasi terhadap para pegawainya. Bagi organisasi, pengembangan karir memberikan beberapa jaminan, bahwa akan tersedia pegawai-pegawai yang akan mengisi posisi-posisi yang akan kosong di waktu mendatang.

Menurut Barzah Latupono (2011), sistim kontrak (outsourcing) diartikan sebagai pemindahan atau pendelegasian beberapa proses bisnis kepada suatu badan penyedia jasa, dimana badan penyedia jasa tersebut melakukan proses administrasi dan manajemen 
berdasarkan definisi serta kriteria yang telah disepakati oleh para pihak. Outsourcing dalam regulasi ketenagakerjaan biasa hanya mencakup tenaga kerja pada proses pendukung (non core business unit). Outsourcing dalam hukum ketenagakerjaan di Indonesia diartikan sebagai pemborongan pekerjaan dan penyediaan jasa tenaga kerja yang diatur dalam Undang-Undang Ketenagakerjaan Nomor 13 Tahun 2003 (Pasal 64, 65 dan 66) dan Keputusan Menteri Tenaga Kerja dan Transmigrasi Republik Indonesia Nomor:Kep.101/Men/VI/2004 Tahun 2004 Tentang Tata Cara Perjanjian Perusahaan Penyedia Jasa Pekerja/ Buruh dan Keputusan Menakertrans Nomor: 220/Men/X/2004 Tentang Syarat-syarat Penyerahan Sebagian Pelaksanaan Pekerjaan Kepada Perusahaan lain. mengingat pengaturan tentang outsourcing (Alih Daya) ini sendiri masih dianggap kurang lengkap, maka pemerintah mengeluarkan Instruksi Presiden Nomor 3 Tahun 2006 Tentang Paket Kebijakan Iklim Investasi. Dalam Inpres tersebut dinyatakan, bahwa outsourcing (alih daya) sebagai salah satu faktor yang harus diperhatikan dengan serius dalam menarik iklim investasi ke Indonesia.

Adapun tujuan dari penelitian ini adalah:

1. Untuk mengetahui variabel pelatihan, disiplin, pengembangan karir serta kinerja karyawan di PT. Gardautama.

2. Untuk mengetahui seberapa besar hubungan dan pengaruh antara variabel pelatihan, disiplin, dan pengembangan karir terhadap kinerja karyawan.

Kerangka konseptual penelitian dapat digambarkan sebagai berikut:

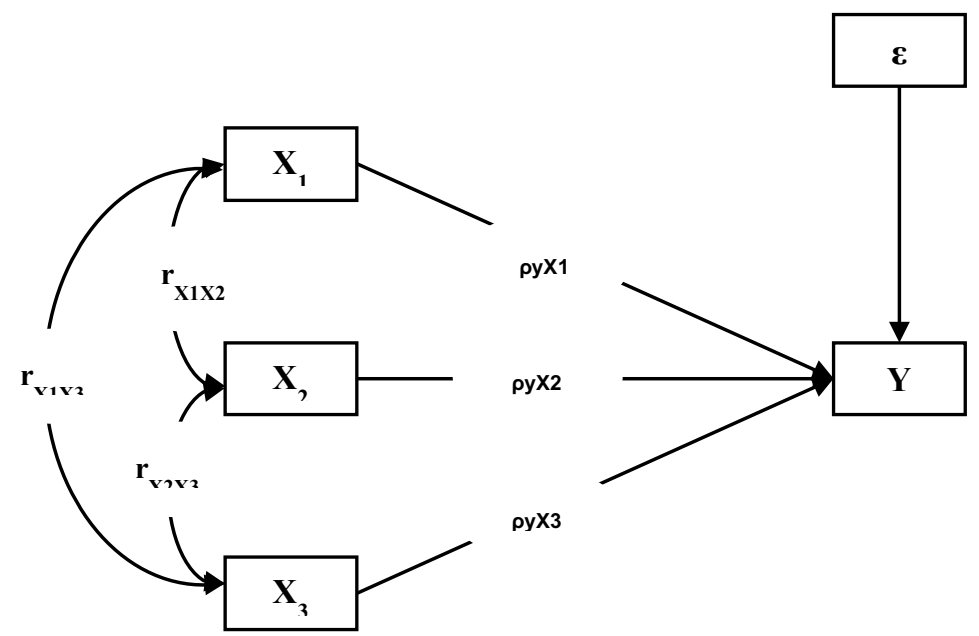

Gambar 1. Kerangka Konseptual Penelitian 


\section{Jurnal Bisnis Manajemen dan Informatika}

Adapun hipotesis yang diajukan adalah sebagai berikut:

H1, H2, dan H3: Pelatihan, disiplin, dan pengembangan karir mempunyai hubungan yang signifikan.

H4: Pelatihan mempunyai pengaruh yang signifikan terhadap kinerja karyawan

H5: Disiplin mempunyai pengaruh yang signifikan terhadap kinerja karyawan

H6: Pengembangan karir mempunyai pengaruh yang signifikan terhadap kinerja karyawan

Untuk menguji hipotesis-hipotesis tersebut digunakan analisis jalur (path analysis) dan untuk mempermudah pengolahannya menggunakan software SPSS 22.0 dengan langkahlangkah sebagai berikut:

1. Menggambarkan analisis jalur dalam sebuah diagram jalur sehingga terlihat paradigma yang mewakili hipotesis penelitian. Diagram jalur dalam penelitian ini tampak pada gambar berikut:

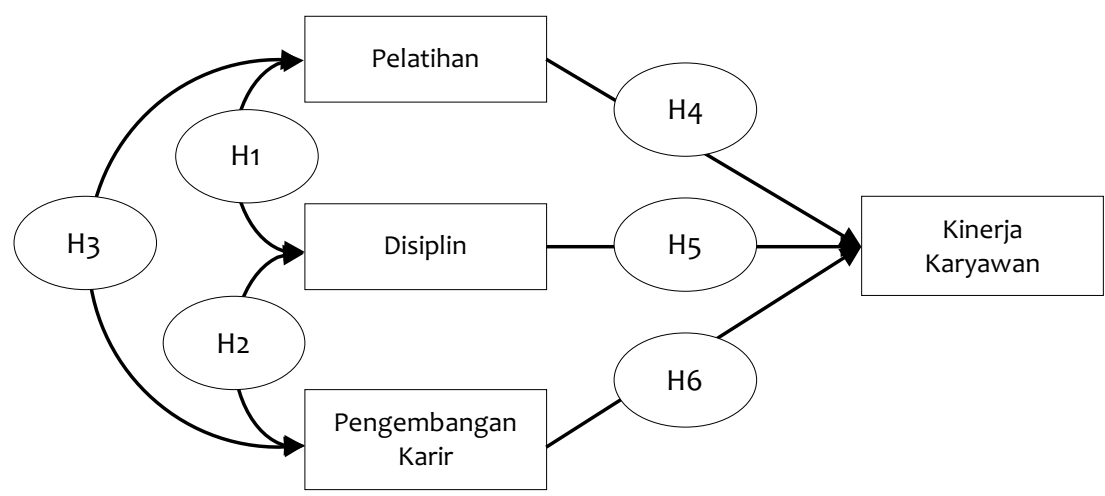

Gambar 2. Analisis Jalur (path analysis)

Keterangan:

$\mathrm{X} 1=$ Pelatihan

$\mathrm{X} 2=$ Disiplin

X3 = Pengembangan Karir

$\mathrm{Y} \quad=$ Kinerja Karyawan

$\mathrm{r}_{\mathrm{X} 1 \mathrm{X} 2}=$ Hubungan antara $\mathrm{X}_{1}$ dengan $\mathrm{X}_{2}$

$\mathrm{r}_{\mathrm{X} 1 \mathrm{X} 3}=$ Hubungan antara $\mathrm{X}_{1}$ dengan $\mathrm{X}_{3}$

$\mathrm{r}_{\mathrm{X} 2 \mathrm{X}_{3}}=$ Hubungan antara $\mathrm{X}_{2}$ dengan $\mathrm{X}_{3}$

$\rho_{\mathrm{yX} 1}=$ Pengaruh antara $\mathrm{X}_{1}$ terhadap $\mathrm{Y}$

$\rho_{\mathrm{yX} 2}=$ Pengaruh antara $\mathrm{X}_{2}$ terhadap $\mathrm{Y}$

$\rho_{\mathrm{yX} 3}=$ Pengaruh antara $\mathrm{X}_{3}$ terhadap $\mathrm{Y}$

$\varepsilon \quad=$ Faktor lainnya yang mempengaruhi $\mathrm{Y}$ selain $\mathrm{X}_{1}, \mathrm{X}_{2}$, dan $\mathrm{X}_{3}$

Adapun persamaan struktur yang dibentuk adalah sebagai berikut:

$$
\mathrm{Y}=\rho_{\mathrm{yX} 1}+\rho_{\mathrm{yX} 2}+\rho_{\mathrm{yX} 3}+\varepsilon
$$


2. Menghitung dan menyusun matrik koefisien korelasi (r) guna mengetahui korelasi antar variabel.

3. Menghitung koefisien jalur $(\rho)$.

4. Menghitung koefisien determinasi $\left(\mathrm{r}^{2}\right)$.

5. Menghitung koefisien epsilon $(\mathcal{E})$ yang tidak diteliti.

6. Melakukan uji signifikansi koefisien jalur secara keseluruhan melalui uji $\mathrm{F}$ dengan kriteria tolak $\mathrm{H}_{0}$ bila $\mathrm{F}_{\text {hitung }}>\mathrm{F}_{\text {tabel }}$.

7. Melakukan uji signifikansi koefisien jalur secara keseluruhan melalui uji t dengan kriteria tolak $\mathrm{H}_{0}$ bila $\mathrm{t}_{\text {hitung }}>\mathrm{t}_{\text {tabel }}$.

\section{METODE}

Riset sumber daya manusia cenderung melibatkan karyawan sebagai obyek yang diteliti. Para karyawan menjadi fokus perhatian para periset dibidang SDM. Aspek-aspek karyawan di perusahaan yang satu bisa jadi berbeda dengan di perusahaan lainnya, misalnya dalam hal komposisi karyawan. Perbedaan jumlah karyawan ini cukup mempengaruhi desain riset. Berkenaan dengan uraian dan gambar di atas, maka Sugiyono (2010:61-62) memberikan pengertian tentang populasi dan sampel, yaitu "Populasi adalah wilayah generalisasi yang terdiri atas: objek/subjek yang mempunyai kualitas dan karakteristik tertentu yang ditetapkan oleh peneliti untuk dipelajari dan kemudian ditarik kesimpulannya. Sedangkan sampel adalah bagian dari jumlah dan karakteristik yang dimiliki oleh populasi”.

Sebelum alat ukur (kuesioner) digunakan, terlebih dahulu dilakukan uji validitas dan uji reliabilitas. Uji validitas dimaksudkan untuk mengetahui apakah instrumen yang digunakan tepat atau sudah mengukur apa yang seharusnya diukur. Oleh karena itu, uji validitas dilakukan pada setiap item dalam kuesioner. Kriteria pengujian validitas, yaitu jika $r_{x y}>0,30$, maka item dari instrumen tersebut dikataka valid. Demikian pula berlaku sebaliknya, jika $r_{x y}<0,30$, maka item dari instrumen tersebut dikatakan tidak valid. Sementara untuk uji reliabilitas, yakni untuk mengetahui keandalan instrumen digunakan metoda belah dua (split half method). Metoda belah dua dilakukan dengan cara membagi instrumen menjadi dua belahan, bisa ganjil-genap dan bisa pula belahan pertama dan kedua, untuk kemudian kedua belahan tersebut dikorelasikan dengan menggunakan rumus yang sama di atas. Kriteria pengujian reliabilitas, yaitu jika $r_{x y}>$ 0,70, maka instrumen dari variabel penelitian tersebut dikatakan reliabel. Demikian juga sebaliknya, jika $r_{x y}<0,70$, maka instrumen dari variabel penelitian tersebut dikatakan tidak reliabel. 


\section{Jurnal Bisnis Manajemen dan Informatika}

Teknik analisis yang digunakan adalah teknik analisis hubungan (Asosiatif). Menurut Sugiyono (2010:89), Hipotesis Hubungan (Asosiatif) adalah suatu pernyataan yang menunjukkan dugaan tentang hubungan antara dua variabel atau lebih. Dari pendapat Sugiyono di atas, maka jelaslah dari penelitian ini akan mendeskripsikan keterikatan antara variabel Pelatihan $\left(\mathrm{X}_{1}\right)$, Disiplin $\left(\mathrm{X}_{2}\right)$, dan Pengembangan karir $\left(\mathrm{X}_{3}\right)$, dengan cara menghitung rerata (mean) dari masing-masing variabel penelitian.

\section{HASIL DAN PEMBAHASAN}

Dari hasil penelitian yang dilakukan terhadap responden yaitu karyawan PT. Gardautama yang berjumlah 389 orang. Selanjutnya jumlah tersebut diambil sampel dengan hasil 160 karyawan. Hasil uji validitas terhadap variabel penelitian, diketahui bahwa seluruh item dari tiap variabel dinyatakan valid, sehingga tidak perlu ada item yang dibuang. Adapun nilai reliabilitasnya adalah:

\begin{tabular}{|c|l|c|c|}
\hline No & \multicolumn{1}{|c|}{ Variabel } & Skor & Kategori \\
\hline 1. & Pelatihan $\left(\mathrm{X}_{1}\right)$ & 0,745 & Reliabel \\
\hline 2. & Disiplin $\left(\mathrm{X}_{2}\right)$ & 0,804 & Reliabel \\
\hline 3. & Pengembangan Karir $\left(\mathrm{X}_{3}\right)$ & 0,908 & Reliabel \\
\hline 4. & Kinerja $(\mathrm{Y})$ & 0,815 & Reliabel \\
\hline
\end{tabular}

Tabel 1. Hasil Uji Reliabilitas

Sumber: Data Primer diolah kembali Tahun 2016.

Dari Tabel 1. di atas, terlihat bahwa seluruh instrumen yang digunakan untuk mengumpulkan data berada di atas 0,70 , sehingga dapat dikatakan bahwa seluruh instrumen penelitian yang digunakan sudah reliabel. Berdasarkan analisis deskriptif masing-masing item pada setiap variabel penelitian, maka dapat direkapitulasikan skor rata-rata dari tiap-tiap variabel penelitian, yaitu sebagai berikut:

\begin{tabular}{|l|c|c|}
\hline \multicolumn{1}{|c|}{ Variabel } & Skor Rata-rata & Kategori \\
\hline Pelatihan $\left(\mathrm{X}_{1}\right)$ & 3,58 & Baik \\
\hline Disiplin $\left(\mathrm{X}_{2}\right)$ & 3,57 & Baik \\
\hline Pengembangan Karir $\left(\mathrm{X}_{3}\right)$ & 3,53 & Baik \\
\hline Kinerja karyawan $(\mathrm{Y})$ & 3,57 & Baik \\
\hline
\end{tabular}

Tabel 2. Rekapitulasi Skor Rata-rata Pendapat Responden Sumber : Kuesioner (diolah) Tahun 2016.

Berdasarkan Tabel 2. di atas, diketahui bahwa variabel pelatihan skor rata-rata 3,58 yakni berada pada kategori Baik; variabel disiplin skor rata-rata 3,57 yakni berada pada kategori Baik; variabel pengembangan karir skor rata-rata 3,53 yakni berada pada kategori Baik; dan variabel kinerja karyawan skor rata-rata 3,57 yakni berada pada kategori Baik. 
Syarat untuk melakukan analisis jalur (path analysis) adalah adanya hubungan diantara variabel bebas $\left(\mathrm{X}_{1}, \mathrm{X}_{2}\right.$, dan $\left.\mathrm{X}_{3}\right)$, dan hubungan antar variabel tersebut dapat dilihat dari koefisien korelasinya. Perhitungan analisis korelasi dengan menggunakan korelasi Pearson Product Moment, dilakukan guna mengetahui seberapa kuat hubungan antara beberapa variabel independen yang diteliti pada penelitian ini. Sugiyono (2010:228), berpendapat bahwa teknik korelasi ini digunakan untuk mencari hubungan dan membuktikan hipotesis hubungan dua variabel bila data kedua variabel berbentuk interval atau ratio, dan sumber data dari kedua variabel atau lebih tersebut adalah sama. Perhitungan ini menggunakan program SPSS 20,00 dan didapat hasil sebagai berikut:

\section{Correlations}

\begin{tabular}{|ll|r|r|r|r|}
\hline & \multicolumn{1}{|c|}{ kinerja } & \multicolumn{1}{c|}{ pelatihan } & \multicolumn{1}{c|}{ disiplin } & \multicolumn{1}{c|}{ karir } \\
\hline \multirow{4}{*}{ Pearson Correlation } & kinerja & 1.000 & .816 & .789 & .823 \\
& pelatihan & .816 & 1.000 & .713 & .871 \\
& disiplin & .789 & .713 & 1.000 & .772 \\
& karir & .823 & .871 & .772 & 1.000 \\
& kinerja & .000 & .000 & .000 \\
Sig. (1-tailed) & pelatihan & .000 & .000 & .000 \\
& disiplin & .000 & .000 & .000 \\
& karir & .000 & .000 & .000 & .000 \\
& kinerja & 160 & 160 & 160 & 160 \\
$\mathrm{~N}$ & pelatihan & 160 & 160 & 160 & 160 \\
& disiplin & 160 & 160 & 160 & 160 \\
& karir & 160 & 160 & 160 & 160 \\
\hline
\end{tabular}

Tabel 3. Hasil korelasi antar Variabel Sumber : hasil olah SPSS 22.00

Hasil analisis jalur (path analysis) melalui analyze regression linier menggunakan SPSS 22,00 dapat diuraikan sebagai berikut:

Coefficients $^{\mathrm{a}}$

\begin{tabular}{|c|c|c|c|c|c|c|}
\hline \multirow{2}{*}{\multicolumn{2}{|c|}{ Model }} & \multicolumn{2}{|c|}{$\begin{array}{l}\text { Unstandardized } \\
\text { Coefficients }\end{array}$} & \multirow{2}{*}{$\begin{array}{c}\begin{array}{c}\text { Standardized } \\
\text { Coefficients }\end{array} \\
\text { Beta }\end{array}$} & \multirow[t]{2}{*}{$\mathrm{t}$} & \multirow[t]{2}{*}{ Sig. } \\
\hline & & $\mathrm{B}$ & Std. Error & & & \\
\hline \multirow{4}{*}{1} & (Constant) & 2.698 & 2.309 & & 1.168 & .244 \\
\hline & pelatihan & .353 & .080 & .3 & 4.403 & .000 \\
\hline & disiplin & .352 & .063 & .3 & 5.586 & .000 \\
\hline & karir & .248 & .087 & .2 & 2.857 & .005 \\
\hline
\end{tabular}

Kemudian pengaruh simultan dari variabel bebas terhadap variabel terikat diketahui nilai koefisien determinasi (square multiple correlation) merupakan koefisien yang digunakan untuk mengetahui besarnya kontribusi variabel independen terhadap perubahan variabel dependen. Hasil analisis jalur dari pengaruh simultan variabel Pelatihan $\left(\mathrm{X}_{1}\right)$, Disiplin Kerja $\left(\mathrm{X}_{2}\right)$, dan 
Pengembangan Karir $\left(\mathrm{X}_{3}\right)$ terhadap Kinerja Karyawan $(\mathrm{Y})$ dengan menggunakan software SPSS 20,00, sebagaimana tersebut dibawah ini:

\begin{tabular}{|l|c|r|r|r|}
\hline Model & R & R Square & \multicolumn{1}{|c|}{ Adjusted R Square } & Std. Error of the Estimate \\
\hline 1 & $.875^{\text {a }}$ & .765 & .760 & 3.85543 \\
\hline
\end{tabular}

a. Predictors: (Constant), karir, disiplin, pelatihan

b. Dependent Variable: kinerja

Tabel 5. Pengaruh Simultan Variabel Bebas terhadap Variabel Terikat

Dengan demikian dapat diketahui hasil penghitungan analisis jalur (path analysis) sebagaimana tampak pada gambar berikut ini:

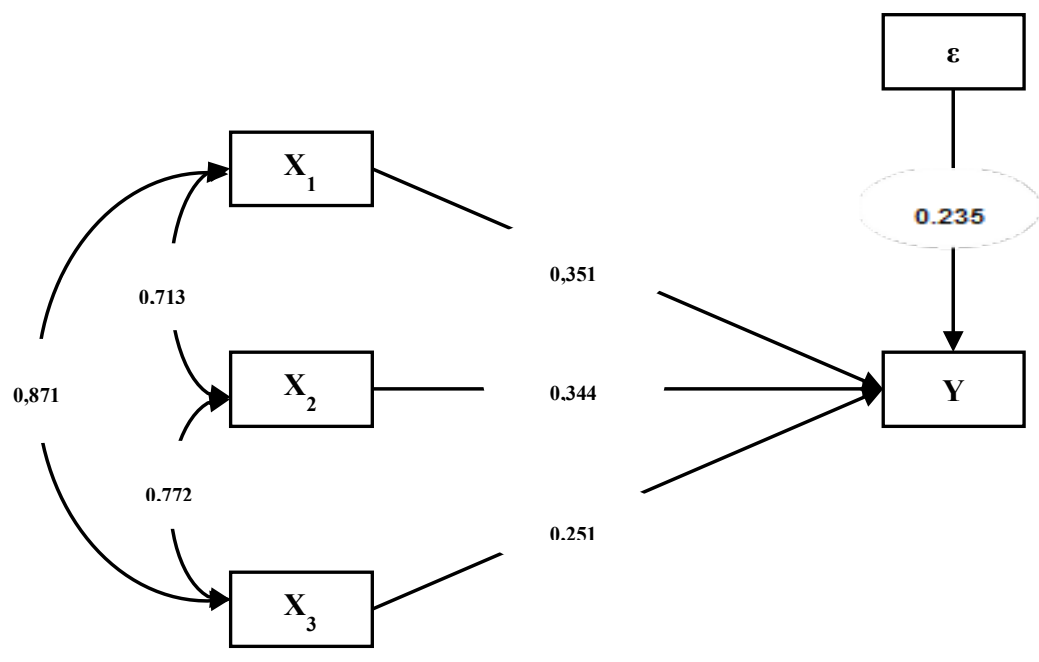

Gambar 3. Hasil Analisis Jalur

Berdasarkan gambar 3. di atas, maka dapat diformulasikan hasil pengujian melalui tabel dibawah ini:

\begin{tabular}{|l|c|}
\hline \multicolumn{1}{|c|}{ Variabel } & Koefisien Jalur \\
\hline Pelatihan $\left(\mathrm{X}_{1}\right)$ & 0,351 \\
\hline Disiplin $\left(\mathrm{X}_{2}\right)$ & 0,344 \\
\hline Pengembangan Karir $\left(\mathrm{X}_{3}\right)$ & 0,251 \\
\hline
\end{tabular}

Tabel 6. Hasil Perhitungan Jalur

Sumber : Hasil perhitungan statistikTabel di atas menggambarkan hasil perhitungan jalur, bahwa variabel $X_{1}$ mempunyai koefisien jalur 0,351 , variabel $X_{2}$ koefisien jalurnya 0,344 , dan variabel $X_{3}$ koefisien jalurnya 0,251 . Hasil tersebut digambarkan dalam persamaan jalur seperti dibawah ini: $\mathrm{Y}=0,351 \mathrm{X}_{1}+0,344 \mathrm{X}_{2}+0,251 \mathrm{X}_{3}+\varepsilon$

Dimana:

$\mathrm{Y} \quad=$ Kinerja Karyawan

$\mathrm{X}_{1} \quad=$ Pelatihan 
$\mathrm{X}_{2} \quad=$ Disiplin

$\mathrm{X}_{3} \quad=$ Pengembangan karir

Sesuai dengan hasil penghitungan analisis jalur, maka berikut disajikan pengaruh total, pengaruh langsung, dan pengaruh tidak langsung setiap variabel sebagaimana terlihat pada tabel 6 berikut ini

\begin{tabular}{|c|c|c|c|c|c|}
\hline \multirow{3}{*}{ Variabel } & \multicolumn{5}{|c|}{ Kinerja Karyawan } \\
\hline & \multirow{2}{*}{$\begin{array}{l}\text { Pengaruh } \\
\text { Langsung }\end{array}$} & \multicolumn{3}{|c|}{ Pengaruh Tidak Langsung } & \multirow{2}{*}{$\begin{array}{c}\text { Pengaruh } \\
\text { Total }\end{array}$} \\
\hline & & $\mathrm{X}_{1}$ & $\mathrm{X}_{2}$ & $\mathrm{X}_{3}$ & \\
\hline Pelatihan & $12,30 \%$ & - & $8,60 \%$ & $7,70 \%$ & $28,60 \%$ \\
\hline Disiplin & $11,90 \%$ & $8,60 \%$ & - & $6,70 \%$ & $27,20 \%$ \\
\hline Pengembangan Karir & $6,30 \%$ & $7,70 \%$ & $6,70 \%$ & - & $20,70 \%$ \\
\hline Pengaruh total & $30,50 \%$ & $16,30 \%$ & $15,30 \%$ & $14,40 \%$ & $76.50 \%$ \\
\hline
\end{tabular}

Tabel 7. Pengaruh Total, Pengaruh Langsung, dan Pengaruh Tidak langsung Sumber: Data primer diolah kembali (2016).

Dari hasil penelitian yang dilakukan diperoleh data, bahwa variabel pelatihan memberikan kontribusi sebesar 26,60\% terhadap kinerja karyawan. Hal ini didukung oleh pendapat yang disampaikan Edwin B. Flippo seperti dikutip Sedarmayanti (2010) yang menjelaskan bahwa pelatihan adalah proses membantu pegawai memperoleh efektivitas dalam pekerjaan sekarang atau yang akan datang melalui pengembangan kebiasaan, pikiran dan tindakan, kecakapan, pengetahuan, dan sikap. Dengan dilaksanakannya pelatihan diharapkan kemampuan kerja yang dimiliki karyawan baik mengenai pengetahuan maupun keterampilan serta sikap dapat meningkatkan sesuai yang diinginkan oleh organisasi/perusahaan. Sedangkan penelitian yang dilakukan oleh Khaerul Akhir Lubis Tahun 2008 dengan judul "Pengaruh pelatihan dan motivasi kerja terhadap kinerja karyawan PT. Perkebunan Nusantara IV (Persero) Medan diperoleh hasil, bahwa variabel pelatihan memberikan kontribusi sebesar 0,376 atau $37,60 \%$ terhadap kinerja karyawan. Dari uraian di atas, maka dapat diketahui bahwa pelatihan merupakan salah satu faktor yang dapat mempengaruhi kinerja karyawan. Dengan adanya pelatihan, diharapkan seluruh potensi yang dimiliki karyawan, yaitu pengetahuan, keterampilan, dan sikap dapat ditingkatkan.

Variabel disiplin memberikan kontribusi sebesar 20,70\% terhadap kinerja karyawan. Berkaitan dengan disiplin kerja, Keith Davis dan John W. Newstrom yang dikutip Hariandja (2009) menyebutkan bahwa beberapa pendekatan untuk meningkatkan disiplin yaitu meliputi disiplin preventif, disiplin korektif, dan disiplin progresif. Ditegakkannya disiplin, bukan hanya 


\section{Jurnal Bisnis Manajemen dan Informatika}

untuk karyawan saja, tetapi juga bagi pengelola perusahaan (manajemen). Dengan diterapkannya disiplin, maka akan muncul dalam diri karyawan tersebut, berupa mental yang baik dan terbina, paham akan tugas dan tanggung jawabnya, serta perubahan sikap perilaku. Dari pendapat di atas, terlihat bahwa pengelola perusahaan (manajemen) mampu mendorong karyawan untuk menjalankan tugasnya masing-masing yang pada akhirnya berpengaruh terhadap kinerja karyawan. Sedangkan variabel pengembangan karir memberikan kontribusi sebesar 20,70\% terhadap kinerja karyawan. Hal ini diperkuat pendapat ahli Sadili Samsudin (2009) yang mengatakan, bahwa pengembangan karir adalah perubahan nilai-nilai, sikap, dan motivasi yang terjadi pada diri seseorang, karena dengan penambahan usia akan menjadi matang. Berkaitan dengan pengembangan karir, Lita Wulantika dalam penelitian yang dilakukan pada Tahun 2005 dengan judul "Pengaruh pengembangan karir dan kepuasan kerja terhadap kinerja karyawan PT. Telkom Kandatel Bandung” diperoleh hasil adanya kontribusi variabel pengembangan karir terhadap kinerja karyawan, yaitu sebesar 0,472 atau 47,20\%. Oleh karena itu untuk mendapatkan tenaga kerja yang kompetitif, diperlukan usaha memberikan bantuan agar para pekerja yang potensial dapat mencapai jenjang karir sejalan dengan usahanya untuk mewujudkan tugas perkembangannya.

\section{KESIMPULAN DAN SARAN}

Berdasarkan hasil analisis data dengan menggunakan path analysis dan pembahasan hasil penelitian yang telah dikemukakan sebelumnya, dapat disimpulkan bahwa pelatihan berpengaruh terhadap kinerja karyawan dengan besarnya pengaruh langsung sebesar 0,123 atau $12,3 \%$ sedangkan pengaruh tidak langsung baik melalui disiplin maupun pengembangan karir sebesar 0, 163 atau 16,3\%, termasuk dalam kategori rendah. Disiplin berpengaruh terhadap kinerja karyawan dengan besarnya pengaruh langsung sebesar 0, 119 atau 11,9\% sedangkan pengaruh tidak langsung baik melalui pelatihan maupun pengembangan karir sebesar 0,153 atau $15,3 \%$, termasuk dalam kategori rendah. Selanjutnya pengembangan karir berpengaruh terhadap kinerja karyawan dengan besarnya pengaruh langsung sebesar 0,063 atau 6,30\% sedangkan pengaruh tidak langsung baik melalui pelatihan maupun disiplin sebesar 0, 144 atau $14,40 \%$ termasuk dalam kategori rendah. Sedangkan pelatihan, disiplin, dan pengembangan karir secara simultan berpengaruh terhadap kinerja karyawan sebesar 0,765 atau 76,50\% berada pada kategori kuat, sedangkan sisanya sebesar 0,235 atau 23,50\% merupakan variabel lain yang tidak diteliti dalam penelitian ini. Dari simpulan di atas, penulis memberikan saran bahwa pelatihan yang dilaksanakan di PT. Gardautama berinovasi sesuai dengan kebutuhan di 
lapangan. Disiplin harus lebih ditingkatkan dan pengembangan karir harus diperhatikan sesuai dengan kinerja yang diberikan karyawan dalam melaksanakan pekerjaannya.

\section{DAFTAR PUSTAKA}

Barzah Latupono. 2011. Perlindungan Hukum dan Hak Asasi Manusia Terhadap Pekerja Kontrak (Outsourcing) di Kota Ambon. Jurnal Sasi. Vol. 17 No. 3: 59-69.

Drucker, Peter. 2008. Peter Drucker Tentang Kepemimpinan dan Efektivitas Eksekutif dalam The Leader of The Future, Visi, Strategi dan Praktek Kepemimpinan Masa Depan Untuk Era Baru. Jakarta. Elex Media Komputindo.

Eli Yulianti. 2015. Pengaruh Pelatihan Terhadap Kinerja Karyawan Grand Fatma Hotel di Tenggarong Kutai Kartanegara.. eJournal Administrasi Bisnis. Vol. 3 No. 4: 900-910.

Fauzan Muttaqin. 2014. Pengaruh Kepemimpinan dan Kompensasi Terhadap Kepuasan Kerja Karyawan Outsourcing Pada PT. BRI (Persero) Tbk. Cabang Lumajang. Jurnal Wiga. Vol. 4 No. 1: 19-33.

Fitz-enz, Fac dan Barbara Davison. 2011. How To Measure Human Resources Management. Jakarta. Kencana Prenada Media.

Hariandja, Marihot Tua Efendi. 2009. Manajemen Sumber Daya Manusia. Jakarta. Gramedia Widiasarana Indonesia: 300.

Instruksi Presiden Republik Indonesia Nomor 3 Tahun 2006 Tentang Paket Kebijakan Iklim Investasi.

Joko Setiawan. 2014. Analisa Pengaruh Pendidikan dan Pelatihan Karyawan Terhadap Peningkatan Kinerja Karyawan Pada PT. GICI Group Batam. Jurnal Akmenbis. Vol. 3 No. 1: 12-18.

Kaswan. 2010. Manajemen Sumber Daya Manusia. Bandung. Putra Praktisi.

Keputusan Menteri Tenaga Kerja dan Transmigrasi RI Nomor: Kep.220/Men/X/2004 Tentang Syarat-syarat Penyerahan Sebagian Pelaksanaan Pekerjaan Kepada Perusahaan Lain. Keputusan Menteri Tenaga Kerja dan Transmigrasi RI Nomor: Kep.101/Men/VI/2004 Tentang Tata Cara Perjanjian Perusahaan Penyedia Jasa pekerja/Buruh.

Samsudin, Sadili. 2009. Manajemen Sumber Daya Manusia. Bandung. Pusaka Setia: 140. Sedarmayanti. 2010. Tata Kerja dan Produktivitas Kerja. Bandung. Mandar Maju: 164. Sugiyono. 2010. Statistika Untuk Penelitian. Bandung. Alfabeta.

Republik Indonesia. 2003. Undang-Undang Republik Indonesia Nomor 13 Tahun 2003 Tentang Ketenagakerjaan. 